Language and Language Teaching Journal http://e-journal.usd.ac.id/index.php/LLT Sanata Dharma University, Yogyakarta, Indonesia

\title{
Discouraging Students' Academic Dishonesty in Flipped Classroom
}

\author{
Lucia Nino Widiasmoro Dewati \\ IPEKA Jakarta \\ lucia.nino.wd@gmail.com \\ DOI: doi.org/10.24071/1lt.2017.200103
}

\begin{abstract}
Flipped Classroom presents teaching process at home through videos, handouts and listening passages before the class session. While in-class time is mostly devoted for questions and answers session, exercises, projects and discussion. The reason flipped classroom is needed for teachers in this era, simply because at the time students do the assignments inside the classroom, teachers would have the opportunities to observe students' interaction, activities, improvement and even to solve students' problem such as academic dishonesty. Thus, the question would be: to what extent is the urgency of implementing flipped classroom as one solution to discourage students' academic dishonesty in writing classes? The study is conducted by employing Action Research. The findings confirm that performing Flipped Classroom is essential in order to discourage students' academic dishonesty while assisting the teacher to observe students' development in writing classes.
\end{abstract}

Keywords: assignment, Flipped Classroom, academic dishonesty

\section{Introduction}

Students' academic dishonesty is one of the massive challenges that teachers have been dealing with for years. Due to technology development, the existence of students' dishonesty, such as plagiarism, is increasing rapidly and barely impossible to avoid. Then, an idea of switching the traditional or face-to-face classroom -where students usually be taught inside the classroom and be given assignments to finish at home as a measurement of their understanding- to a completely 'flipped' classroom where students are taught at home and also finish their assignments inside the classroom so that they may get personal assistance and even observation from the teachers. By being observed and assisted during completing the assignment, it would be a turning point to minimize students' academic dishonesty.

Flipped classroom was initially inspired by Jonathan Bergman and Aaron Sams in 2008 to overcome students' absences in school. "Basically the concept of a flipped class is this: that which is traditionally done in class is now done at home, and that which is traditionally done as homework is now completed in class." (Bergman \& Sam, 2012)

Starting with software to record teachers' lesson, absent student could study any materials they had missed. Nowadays, the idea of flipped classroom, not only to support absent students but also to encourage students exploring much 
information of the topic discussed before attending the class. Employing Flipped Classroom is also beneficial for students to reiterate difficult information at home by themselves after the class because flipped classroom creates greater engagement and higher learning motivation between students and teacher. (Tune et al, 2013)

Flipped Classroom enables teacher to create or prepare videos and other materials before the class is started. Students could access the materials at home such as video and handouts by retrieving them on Class Website or suggested sources. After the students are equipped with advanced knowledge needed, the teacher could assess students' understanding at class by having questions and answers or giving them assignments. Besides assessing students' understanding, Flipped Classroom could also assist teachers to discourage students to 'copy' their classmates' assignments or download them online. It is because at the time students do the assignments inside the classroom, teachers would have the opportunities to observe students' interaction, activities, improvement and even problem. "In the Flipped Learning model, teachers shift direct learning out of the large group learning space and move it into the individual learning space, with the help of one of several technologies." (Hamdan et al., 2013, p.4)

The basic concept of flipped classroom has been widely initiated in Indonesia since 2000, started from Competency Based Curriculum in which students are highly recommended to be independent learners. Then, the latest curriculum, 2013 Curriculum emphasizes more to character education rather than only focusing on academic achievement. Meanwhile, at the same time, students' learning independency is still being expected. Flipped Classroom provides opportunities for teachers in order not only to observe students' academic achievements but also monitor students' attitudes, behaviour, social relation and students' characters development.

Academic dishonesty is one of major issues among students for years. Cheating and plagiarism are only some examples of academic honesty violation that both teacher and students often deal with. "Academic dishonesty includes behaviours such as cheating on exam, copying other students' home work and assignment and plagiarism" (Jensen, L. A et al, 2002). Moreover, in this digital era when everything is easily provided and accessible by double clicking, unawareness of doing plagiarism can be something usual. Educating students the importance of avoiding plagiarism during their education, especially for high school students, is something imperative because societies, for example universities, have strict rules and penalties for students who did academic dishonesty (Baird, 1980). On the contrary, high schools where students study, be taught and be disciplined before studying in university, still considered academic honesty violations as trivial because the teachers still have not found the effective solution for educating the students about academic dishonesty, the effects, and particularly discouraging students to do it.

To prevent students' dishonesty, applying flipped classroom is very essential. The reason is because students sometimes are not aware that they commit plagiarism so that by providing individual assistance to observe students' activities, problems and progress, teachers would have direct opportunities to help 
students avoid academic honesty violation. Davis (2012) stated desirable deterrent, such as asking students to not cheat, could prevent them doing academic dishonesty. Besides, it does meet the education curriculum expectation of improving character education, such as honesty. Those expectations are possible and could be done by allowing students to do the assignment in the classroom while teachers observing students' behaviour personally to assess their honesty.

\section{Method}

Being a researcher who also happens to teach in classes contributes massive opportunity to observe students' problem in the classroom. The teachers may also have opportunities of self-reflecting after the teaching and learning process. Knowing the issues and the problematic situation occurred in the classroom encourages researcher to design a plan to improve concrete enhancement for both teacher and students. Teachers might initiate the research in order to address any possible and effective solution towards the real issues in their teaching. One of effective methods discussed in this study is Action Research.

Teachers with enormous loads and responsibilities are sometimes unable to make time to conduct research. A teacher whose role is also as a researcher requires an effective methodology to manage the research while teaching. Performing Action Research enabling and empowering teachers to broaden educational consideration, to develop and to evaluate their teaching role.

"Action research offers a valuable opportunity for teachers to be involved

in research which is felt to be relevant, as it is grounded in the social context of the classroom and the teaching institution, and focuses directly on issues and concerns which are significant in daily teaching practice." (Burns, 2010).

By conducting action research in classes, teaching learning improvements, students' activities, teachers' monitoring and evaluation become highly visible and observable. Teachers find problem in their teaching and proceed to create solution by implementing theories and findings of the current research based on observation and reflection (Hong et al., 2013)

The action research study consists of six stages, namely, identifying an issue, planning a proposal, taking action, collecting-analyzing the data, improving the practice and summarizing-sharing the findings.

\section{Findings and Discussion}

The subjects in this research are high school students grade XI. Prior to the study, the researcher studied the subjects' awareness of academic dishonesty and subjects' final writing. The data were collected and kept as the preliminary data.

The study is to investigate to what extent is the benefits of applying flipped classroom in order to discourage students' academic dishonesty. In order to achieve the purpose, several stages needed to be done, for example deciding on the topic to discuss. The topic that the students need to write is News Report. News Item is chosen as the main topic of the writing because students are familiar with the texts since they can be accessed and found almost everywhere. News Item was also obligatory content to teach in 2006 curriculum. Secondly, the subjects that were observed in this study are $131 \mathrm{XI}$ grade students. 


\section{Identifying the Challenges in Writing}

The researcher started collecting initial information by interviewing sample subjects on their understanding of academic dishonesty and their writing problems. The findings revealed that the sample subjects were still unaware of the kinds of academic dishonesty and the impact of doing academic dishonesty to some extent. The subjects also had difficulties in brainstorming, connecting their ideas and realising their vision into writing. Lack of related information, poor time management, negligence of the impact of academic dishonesty, inability to elaborate and initiate main ideas to detailed information were some motives why students kept doing plagiarism.

\section{Planning Sets of Teaching Instructions and Materials.}

After noticing the subjects' issues in writing, the researcher employed Flipped Classroom approach because it is suitable to gain teacher-students learning engagement since it creates personal and individual assistance.

Table 1: Timeline

\begin{tabular}{|l|l|}
\hline \multirow{5}{*}{1 st Month } & Introducing the topic and text structure \\
\cline { 2 - 2 } & Brainstorming \\
\cline { 2 - 2 } & Library Research \\
\cline { 2 - 2 } & Mindmapping \\
\hline \multirow{5}{*}{ 2nd Month } & How to avoid plagiarism \\
\cline { 2 - 2 } & Drafting \\
\cline { 2 - 2 } & Feedbacks \\
\cline { 2 - 2 } & Final writing \\
\hline 3rd Month & Analyzing the data \\
\hline
\end{tabular}

During the planning stage, the teacher prepared a set of videos, presentation and handout which were going to be watched, read and done by students. The teacher also provided alternative way if the students needed further and repeated information before and after the class. Preparing checklist feedback from peer and teacher is imperative during the forthcoming process in order to help completing students' writing and to meet the expectation.

\section{Taking Action by Doing Flipped Classroom}

During 3 months of teaching, the researcher did not only explain and demonstrate the text structure of News Item but also explained what was academic dishonesty, the types of academic dishonesty, how to avoid plagiarism, including how to brainstorm ideas, conduct library research, write draft and also conduct peer feedback. The researcher also designed various supportive assignments for the subjects in order to enhance the awareness and avoid academic dishonesty during flipped classroom.

Procedures: The study lasted approximately three months, which was divided into two phases. The first phase went on for one month while the second phase lasted for two months. In the end of the second phase, the researcher collected the 
data of subjects' writing result while interviewing the subjects about their awareness of academic dishonesty and their difficulties during the writing process.

The first stage: A constructed teaching plan was determined, the teacher divided the observation into pre-writing, during-writing and post-writing activities. The researcher arranged materials before students started writing. Secondly, the teacher set some materials such as handouts and worksheet, also prepared supporting videos and presentation that students could watch or study before and after the class. The set of materials covered the text topic, an encouragement of avoiding academic dishonesty and the tips and tricks.

In while-writing stage, the researcher only assisted the students during their writing. In case there were questions related to the topic and problem faced by the students, this stage is highly beneficial to give further explanation personally. Although the students were given opportunities to decide their news topic and conducted independent library study, teacher could still provide full attention and observation since the writing process was done at class.

In post-writing stage, the students were required to get feedback, suggestion and evaluation of their complete draft from their peer. The feedback was in form of checklist covering both oral and written suggestion. In this stage, the teacher also gave feedback and suggestion on students' draft in order to help them understand and notice parts on their writing that they could improve. Teacher also collected their improvement in form of score for data collection.

When the subject had done the writing, the researcher could observe and analyze the efficiency of flipped classroom to discourage students' academic dishonesty in writing News Item.

\section{Collecting-Analyzing the Data}

There are some data obtained to analyze and observe the effectiveness of teaching approaches in order to discourage students' dishonesty. Beside students' portfolio which contained students' writing, field notes, classroom observation and writing score, an interview was also conducted to acquire adequate data. The 1st data of flipped classroom implementation can be observed on Table 2:

Table 2. Students' Writing in Drafting Stage

\begin{tabular}{|c|c|c|}
\hline Paraphrasing & Quoting & Citing \\
\hline $80 \%$ & $86 \%$ & $66 \%$ \\
\hline
\end{tabular}

Based on Table 2, after the students were equipped and informed with academic dishonesty and steps of avoiding it, students could present their writing and supported source by paraphrasing and quoting appropriately. The number of students who can quote properly is high because students were also equipped by studying reported speech. The percentage of students who are able to paraphrase is also high although some of them still found it difficult to rewrite the statements with their own words. Citing is still considered the most difficult thing to do for students because students were still unaware of the importance of mentioning the source of their data, picture, idea or statement. Meanwhile, not mentioning the source in the end of news item is usually done for space efficiency reason. 


\section{Improving the Practice}

After the students were given positive and encouraging peer feedback and teacher's feedback towards their writing, they were expected to revise their writing before they wrote the final draft. After finishing the final draft, the result was improved rapidly. The data can be seen on Table 3:

Table 3. Students' Writing After the Feedback

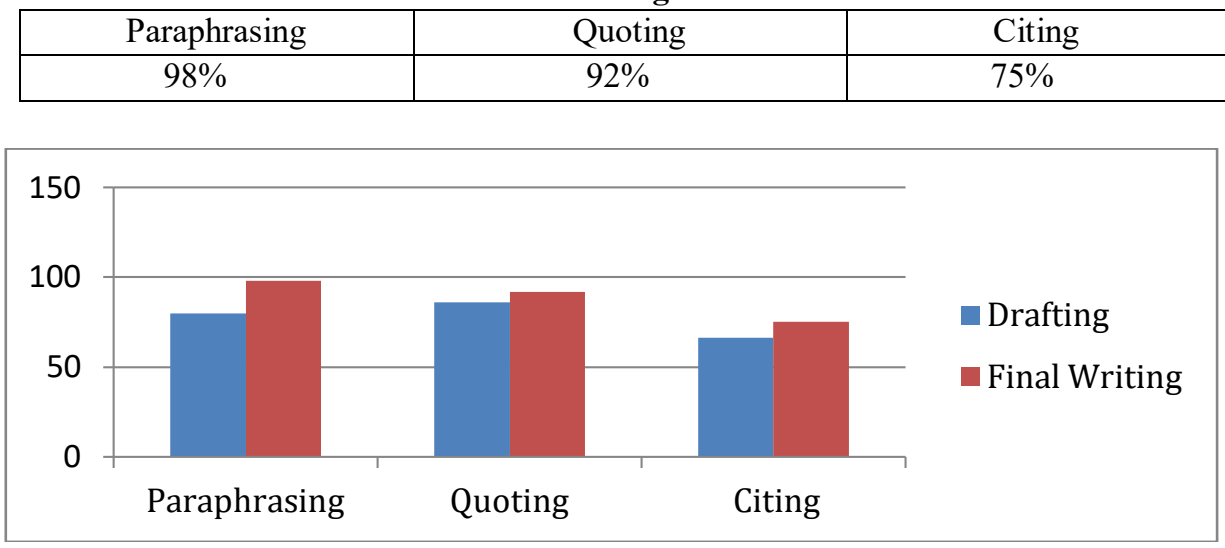

Figure 1. Students' Writing Improvement Chart

Students' writing improvement can be seen in Figure 1. Most of the students showed prompt improvement in their writing by showing their awareness of discouraging academic dishonesty by mentioning the source when it was needed. Percentage of students who did paraphrasing in their News Item increased by $18 \%$. The number of students who put quotation in their writing also rose up to $6 \%$. While students who were highly aware of citing also enhanced from $66 \%$ to $75 \%$. Based on the students' interview, besides being more confident in writing, students did learn the urgency of mentioning the source and avoid themselves from unintentionally commit academic dishonesty.

\section{Summarizing-Sharing the Findings}

Based on the data collection and discussion, the subjects' paraphrasing accuracy and quoting in news writing are steadily improved. The subjects did extremely well from ingenuous to well-known writer. They learnt the urgency in mentioning the source to support their writing and avoid unintentional plagiarism. The subjects also learnt organizing ideas into well-structured writing. On the other hand, from the teachers' point of view, action research does enable them to reflect on their teaching performance more scientifically and objectively. The roles that teachers accomplish through flipped classroom also vary from one circumstance to another. Teachers are not only educators but also have roles as partners, organizers and motivators. Discouraging academic dishonesty is possible when students' initiative is equally improved. 
The researchers shared the findings to another colleagues as a part of action research. The purpose is also to broaden self-awareness of avoiding academic dishonesty among practitioners, enhancing teaching practice through evaluation and contributing better writing development for students.

\section{Conclusion}

This study explains the action research of the implementation of flipped classroom in writing classes. In return, the study enables teachers to have a better understanding of the importance in performing flipped classroom because of its' contribution to discourage the students from committing academic dishonesty. Although the study has not included massive subjects, more empirical studies, reflective evaluation from the similar studies and collaborative action research studies are necessary so that enormous implication can be observed to help the teacher shares awareness of the necessity to discourage students' academic dishonesty at the earliest convenience.

There are many EFL learning theories used in the classroom and learning English is still considered essential to meet the curriculum expectation. Furthermore, the technology development and information exposure that language learners nowadays are exceedingly familiar with could support students to enhance their writing skill and also other skills. Therefore, it also becomes the teachers' responsibility to keep encouraging students to write more, educating and raising awareness of academic dishonesty among students. The preparation for flipped classroom could be absolute but the implication is surely assuring.

Action research provides researcher with a tool by which they can directly identify the issues during the teaching and learning process and decide on the best solution and continuously test them in the teaching and learning practice. By integrating language theories into teaching practice, teachers may improve their teaching and enhance their understanding in teaching theories. Teachers can assist the students to improve and teachers can certainly ensure their career development.

\section{References}

Baird, J. S. (1980). Current trends in college cheating. Psychology in the Schools, 17(4), 515-522.

Burns, A. (2010a). Doing action research for English language teachers. A guide for practitioners. New York: Routledge.

Butt, A. (2014). Student views on the use of a flipped classroom approach: Evidence from Australia. Business Education \& Accreditation, 6(1), 33.

Brydon-Miller, M., Greenwood, D. and Maguire, P. (2003). "Why Action Research?” in Action Research London: Sage Publications Vol.[1](1) July 2003 P9-28

Bergman, J., \& Sams, A. (2012). Flip your classroom. International Society for Technology in Education, 20. Burns, A. (2003). Collaborative action research for English language teachers. Ernst Klett Sprachen. 
Davis, S. F., Grover, C. A., Becker, A. H., \& McGregor, L. N. (1992). Academic dishonesty: Prevalence, determinants, techniques, and punishments. Teaching of Psychology, 19(1), 16-20.

Flumerfelt, S., \& Green, G. (2013). Using Lean in the Flipped Classroom for At Risk Students. Educational Technology \& Society, 16(1), 356-366.

Hamdan N, McKnight P, McKnight K, Arfstrom KM. A Review of Flipped Learning: Flipped Learning Network. Pearson Education, and George Mason University.; 2013. www.flippedlearning.org/cms/lib07/VA01923112/Centrici ty/Domain/41/LitReview_FlippedLearning.pdf?utm_source=hootsuite\&utm campaign=hootsuite (accessed 10 August 2016)

Jensen, J. L., Kummer, T. A., \& Godoy, P. D. D. M. (2015). Improvements from a flipped classroom may simply be the fruits of active learning. CBE-Life Sciences Education, 14(1), ar5.

Jensen, L. A., Arnett, J. J., Feldman, S. S., \& Cauffman, E. (2002). It's wrong, but everybody does it: Academic dishonesty among high school and college students. Contemporary Educational Psychology, 27(2), 209-228.

Ma, H., Chen, Z. Y., \& Pan, Z. Y. (2013, August). A case study of collaborative action research: lexical chunk theory and its implication on reading performance. In 2013 International Conference on Applied Social Science Research (ICASSR-2013). Atlantis Press.

Marzano, R. J. (2003). What works in schools: Translating research into action. ASCD.

Marzano, R. J., Marzano, J. S., \& Pickering, D. (2003). Classroom management that works: Research-based strategies for every teacher. ASCD.

Milman, N. B. (2012). The flipped classroom strategy: What is it and how can it best be used?. Distance Learning, 9(3), 85 .

Roehl, A., Reddy, S. L., \& Shannon, G. J. (2013). The flipped classroom: An opportunity to engage millennial students through active learning. Journal of Family and Consumer Sciences, 105(2), 44.

Rutherfoord, R. H., \& Rutherfoord, J. K. (2013, October). Flipping the classroom: Is it for you?. In Proceedings of the 14th annual ACM SIGITE conference on Information technology education (pp. 19-22). ACM.

Tucker, B. (2012). The flipped classroom. Education next, 12(1)

Tune JD, Sturek M, Basile DP. Flipped classroom model improves graduate student performance in cardiovascular, respiratory, and renal physiology. $A d v$ Physiol Educ 2013;37:316-320. 